\title{
Protokol Evaluasi Infeksi Bakteri Pre- dan Pasca-Transplantasi Hati Anak
}

\author{
Mulya Rahma Karyanti, Nina Dwi Putri, Hanifah Oswari \\ Departemen Ilmu Kesehatan Anak Fakultas Kedokteran Universitas Indonesia/RSUPN Dr. Cipto Mangukusumo, Jakarta
}

Infeksi pre- dan pasca-transplantasi hati dipengaruhi oleh gangguan sistem imunonlogi resipien karena penggunaan obat-obat imunosupresi. Komplikasi infeksi tersebut merupakan penyebab penting kejadian infeksi terhadap morbiditas dan mortalitas pada anak anak yang menjalani transplantasi hati. Obat-obatan profilaksis sebelum dan setelah operasi yang direkomendasikan disesuaikan dengan pola mikroba yang berkaitan di setiap rumah sakit. Uji tapis infeksi bakteri penting untuk mencegah terjadinya infeksi pascatransplantasi hati. Komplikasi terjadinya infeksi sekunder oleh bakteri disebabkan oleh karena penggunaan alat-alat invasif dalam jangka waktu yang lama seperti kateter vena sentral, kateter akses arterial, endotracheal tube, kateter ureter, dan sebagainya. Keberhasilan efektivitas pengobatan antimikroba ditentukan oleh pengelolaan pemasangan atau pelepasan semua alat invasif dan pengontrolan infeksi di rumah sakit. Sari Pediatri 2019;21(1):66-72

Kata kunci: transplantasi hati, infeksi bakteri, antibiotik, immunosupresi, anak

\section{Guideline to Evaluate Bacterial Infection Pre- and Post-Liver Transplantation in Children}

Mulya Rahma Karyanti, Nina Dwi Putri, Hanifah Oswari

Pre and post liver tranplantation infections will be affected by recipient immune system that can be modulated by immunossuppresion drugs. Infection complications are important cause of morbidity and mortality in children undergoing liver transplantation. Recommended pre- and post-operative prophylaxis varies according to the pathologic agent which depend on the microbial pattern in each hospital. Bacterial infection screening is important to prevent post liver transplantation infection. Secondary bacterial infection complications caused by prolong use of invasive devices such as central venous catheter (CVC), arterial catheter, endotracheal tube, ureter catheter, etc could occur. The effectiveness of antimicrobial therapy is determined by the successful of controlling the use or removal all invasive devices and hospital infection control. Sari Pediatri 2019;21(1):66-72

Keywords: liver tranplantation, bacterial infection, antibiotic, immunosuppressive, children

Alamat korespondensi: Mulya Rahma Karyanti. Departemen Ilmu Kesehatan Anak RSUPN Cipto Mangukusumo, Fakultas Kedokteran Universitas Indonesia. Jl. Diponegoro No.71 Salemba, Jakarta Pusat. Email: karyanti@ikafkui.net 
I nfeksi pasca-transplantasi hati dapat menyebabkan waktu perawatan menjadi lebih lama dan meningkatktan biaya perawatan di rumah sakit. Sekitar 75\% infeksi bakteri terjadi pada satu bulan pertama setelah transplantasi hati. Sebagian besar kasus disebabkan oleh infeksi endogen yaitu infeksi bakteri Gram negatif dan jamur yang berkolonisasi pada sistem organ resipien. Di Rumah Sakit Umum Pusat Cipto Mangunkusumo tahun 2010 - 2018 terdapat 110 kasus infeksi pasca-transplantasi yang terjadi dengan 77 kasus diantaranya disebabkan oleh infeksi bakteri. Lima puluh sembilan persen kasus infeksi disebabkan oleh bakteri gram negatif. Sebagian besar infeksi disebabkan oleh Klebsiella pneumonia. Oleh sebab itu, dibutuhkan protokol panduan pemberian antibiotik disertai dengan diagnosis infeksi baik pre- maupun pasca-transplantasi, dengan mempertimbangkan pola mikrobiologi lokal dan pola resistensi agar efektif dan efisien. ${ }^{1-3}$ Artikel ini disusun sebagai protokol untuk mendeteksi infeksi bakteri pre- dan pasca-transplantasi hati pada anak untuk mencegah dan mengurangi transmisi infeksi bakteri.

Protokol ini dibuat berdasarkan klasifikasi level of evidence yang dikeluarkan oleh Oxford Centre for Evidence-based Medicine yang dimodifikasi untuk keperluan praktis. Peringkat bukti yang digunakan adalah (1) level I, yaitu meta analisis atau Randomize Clinical Trial (RCT) double blind (uji klinis acak tersamar ganda); (2) level II, yaitu RCT non double blind (uji klinis acak tidak tersamar ganda terandomisasi / non randomisasi); level III, yaitu studi observasional (kohort, potong lintang, kasus kontrol); level IV, yaitu konsensus atau pendapat ahli.

Derajat rekomendasi berdasarkan peringkat bukti dibuat sebagai berikut, rekomendasi A bila berdasar pada bukti level I, rekomendasi B bila berdasar pada bukti level II, rekomendasi C bila berdasar pada bukti level III, rekomendasi D bila berdasar pada bukti level IV.

\section{Etiologi infeksi}

Baik bakteri Gram positif dan negatif dapat menyebabkan infeksi pada transplantasi hati. Pada prosedur transplantasi hati, rongga dada, mediastinum, rongga peritoneum maupun saluran cerna dapat terlibat sehingga keterlibatan polimikrobial perlu dipertimbangkan berdasarkan gejala yang ditemukan.
Bakteri Gram positif, seperti Streptococcus pneumoniae, dapat menjadi salah satu etiologi, terutama jika pasien telah mendapatkan obat-obatan imunosupresi. Patogen yang berkolonisasi pada saluran pernapasan seperti Pseudomonas aeruginosa juga sering ditemukan sebagai penyebab infeksi dan dapat menjadi patogen. Infeksi oleh bakteri gram negatif lain seperti Eschercia coli, Klebsiella pneumoniae dan Acinetobacter baumanii sering ditemukan juga menjadi penyebab infeksi pasca transplantasi hati baik ditemukan pada biakan darah, drain maupun sputum pasien transplantasi hati, terutama yang menjalani perawatan lama di rumah sakit. ${ }^{2,4,5}$

1. Evaluasi dan Tata Laksana Infeksi Bakteri PreTransplantasi

a. Uji Tapis Methicillin-resistant S. aureus (MRSA) dan Vancomycin-resistant enterococcal (VRE) Pemilihan antibiotik profilaksis pada pasien transplantasi hati dilakukan dengan mempertimbangkan kolonisasi bakteri sebelum transplantasi, adanya kolangitis kronik, riwayat pembedahan kasai sebelumnya, re-tranplantasi, adanya kolestasis, tingginya skor PELD (Pediatric End-stage Liver Disease), serta adanya kesulitan pembedahan. Uji tapis infeksi bakteri diperlukan sebagai salah satu pertimbangan untuk menentukan antibiotik profilaksi. Uji tapis dilakukan dengan cara melakukan swab nasal, inguinal, aksila untuk MRSA, sedangkan untuk uji tapis VRE dilakukan dengan melakukan kultur feses. (kepustakaan SHEA terlampir). Secara umum, uji tapis pasca transplantasi meliputi kultur darah aerob dan anaerob, kultur urin aerob, kultur feses aerob, urinalisis, feses lengkap, dan tinja parasit. ${ }^{4}$

\section{b. Profilaksis sebelum transplantasi antibiotik}

Secara umum, semua pasien transplantasi hati dibagi menjadi risiko rendah dan tinggi. Pasien transplantasi risiko tinggi adalah pasien yang melakukan transplantasi ulang, pembedahan koledokojejunostomi, serta donor seropositif CMV dengan resipien seropositif CMV. Sementara, pasien transplantasi risiko rendah adalah semua pasien transplantasi hati yang tidak memenuhi kriteria risiko tinggi. ${ }^{5}$

Pasien transplantasi hati secara umum diberikan antibiotik profilaksis ampisilin sulbactam 
dengan dosis $50 \mathrm{mg} / \mathrm{kg}$ drip 30 menit maksimal 1 jam sebelum transplantasi hati. Dengan mempertimbangkan waktu paruh antibiotik, pemberian antibiotik ampisilin sulbactam dilakukan kembali setiap 2-4 jam intraoperatif dengan durasi pemberian antibiotik 24 jam untuk kasus yang tanpa komplikasi dan 72 jam untuk kasus dengan komplikasi. ${ }^{4}$

Profilaksis sebelum transplantasi hati dengan risiko rendah diberikan ampicillin/sulbactam 50 $\mathrm{mg} / \mathrm{kgIV}$. Sedangkan pada pasien dengan risiko tinggi diberikan piperacilin/tazobactam $100 \mathrm{mg} /$ kgIV. Profilaksis antibiotik sebelum dan setelah transplantasi hati tertera pada Tabel $1 .^{6}$

Alergi obat ditandai dengan adanya tanda dan gejala pada pasien kesulitan pada sistem respirasi, hipotensi, ruam, dan gatal-gatal.

Catatan: bila pasien baru saja mendapat terapi antimikroba pada infeksi aktif, diperlukan konsultasi dengan tim transplantasi hati.

\section{c. Tata laksana infeksi bakteri pre-transplantasi}

Rekomendasi untuk manajemen MRSA pada pasien dengan solid organ transplant (SOT) terdiri atas dua tahap. Pertama, uji tapis pra-transplantasi untuk MRSA nasal carriage dan dekolonisasi dengan mupyrocin direkomendasikan sebelum transplantasi pada area dengan prevalensi yang rendah sampai sedang (B). Kedua, dekolonisasi universal dengan mupyrocin nasal dan mandi setiap hari dengan chlorhexidine-impregnated cloths selama di PICU pasca-transplantasi harus dipertimbangkan pada area dengan prevalensi yang tinggi (A). ${ }^{7}$

Rekomendasi untuk manajemen VRE pada pasien dengan solid organ transplant (SOT), yaitu uji tapis rutin di area dengan prevalensi rendah atau sedang tidak direkomendasikan. Namun, selama terjadi wabah atau pada daerah dengan prevalensi yang tinggi, surveilans aktif dapat diindikasikan (B). Pasien yang terkolonisasi dengan VRE diisolasi dalam ruangan dengan satu tempat tidur dan diterapkan kewaspadaan kontak (B). Tindakan dekolonisasi tidak direkomendasikan (D). ${ }^{7}$

Linezolid direkomendasikan untuk tata laksana bakteremia pada ampicillin-resistant VRE atau pasien dengan alergi penisilin (B). Pada infeksi VRE tanpa bakterimia direkomendasikan untuk menggunakan Linezolid (Tabel 2). ${ }^{7}$

Identifikasi kolonisasi bakteri multi-drug resistant (MDR), seperti MRSA, ExtendedSpectrum Beta Lactamase (ESBL) dan VRE, berguna untuk menentukan profilaksis antibiotik pada beberapa kondisi tertentu, misalnya profilaksis selama prosedur atau cakupan antibiotik empiris dalam menghadapi komplikasi infeksi setelah transplantasi(B). ${ }^{2}$ Kolonisasi dapat dideteksi dengan menggunakan kultur swab nasal/ kulit atau metode identifikasi cepat seperti PCR atau chromogenic agar. ${ }^{4}$

Pemilihan jenis antibiotik untuk profilaksis sebelum operasi ditentukan berdasarkan data epidemiologi setempat, secara umum generasi ketiga cephalosporin (cefotaxime) dan ampicillin atau piperacillin-tazobactam dapat digunakan sebagai profilaksis yang diberikan selama 1-3 hari. Cefotaxime memberikan cakupan terhadap aktifitas kuman Staphylococcus dan ampicillin memiliki efek anti-enterococci, sementara aktifitas antimikroba piperacillin-tazobactam mencakup Enterobacteriaceae, Enterococci, dan Pseudomonas. ${ }^{1}$

Mandi clorhexidine dan pemberian mupyrocin $2 \%$ intranasal dapat membantu dekolonisasi MRSA dan isolasi pasien dapat mencegah infeksi

Tabel 1. Profilaksis antibiotik sebelum dan setelah transplantasi hati ${ }^{6}$

\begin{tabular}{|c|c|c|}
\hline Indikasi & Dosis antimikroba pre-operasi & Dosis antimikroba post-operasi \\
\hline $\begin{array}{l}\text { Transplantasi hati dengan risiko } \\
\text { rendah }\end{array}$ & $\begin{array}{l}\text { Anak }(<40 \mathrm{~kg}) \text { : } \\
\text { Ampicillin } / \text { sulbactam } 50 \mathrm{mg} \\
\text { (komponen ampicillin ) } / \mathrm{kgIV} \text { x } 1 \\
\text { dosis, diberikan } 1 \text { jam sebelum operasi }\end{array}$ & $\begin{array}{l}\text { Anak (<40kg): } \\
\text { Ampicillin/sulbactam } 50 \text { mg (komponen } \\
\text { ampicillin )/kgIV per } 6 \text { jam x } 24 \text { jam }\end{array}$ \\
\hline $\begin{array}{l}\text { Transplantasi hati dengan risiko } \\
\text { tinggi }\end{array}$ & $\begin{array}{l}\text { Anak (<40kg): } \\
\text { Piperacilin/tazobactam } 100 \mathrm{mg} \\
\text { (komponen piperacilin )/kgIV x } 1 \\
\text { dosis }\end{array}$ & $\begin{array}{l}\text { Anak }(<40 \mathrm{~kg}) \text { : } \\
\text { Piperacilin/tazobactam } 100 \mathrm{mg} \\
\text { (komponen piperacilin }) / \mathrm{kgIV} \text { per } 8 \text { jam } \\
\text { infus selama } 4 \text { jam x } 24 \text { jam }\end{array}$ \\
\hline
\end{tabular}


VRE dan bakteri Gram-negatif MDR. Pilihan antibiotik definitif tergantung hasil kultur. ${ }^{1}$

\section{Evaluasi dan Tata Laksana Infeksi Pasca- Transplantasi}

\section{a. Periode infeksi pasca-transplantasi}

Berdasarkan waktu penyebab terjadinya infeksi pascatransplantasi hati dibagi menjadi tiga periode. Pertama, periode kurang dari satu bulan pasca-transplantasi (infeksi awal pasca-transplantasi) meliputi infeksi operasi, infeksi oportunistik, dan infeksi berasal dari donor lebih sering ditemukan. ${ }^{1}$ Infeksi bakteri $(S$. aureus) dan jamur (Candida) paling banyak didapatkan pada periode ini. Kedua, periode 2-12 bulan setelah transplantasi (infeksi periode menengah), infeksi yang didapat dari komunitas dan infeksi oportunistik lebih sering terjadi. Pada periode ini, infeksi virus (CMV dan EBV) lebih banyak ditemukan. ${ }^{8}$ Ketiga, periode lebih dari 12 bulan (infeksi lambat pasca-transplantasi) lebih jarang terjadi dan dapat meningkat (Tuberculosis, Cryptococcus, Rhodococcus, Nocardia). Pada umumnya, infeksi yang terjadi sama dengan anak normal lainnya. ${ }^{1,9}$

Pada masa awal pasca-transplantasi evaluasi dilakukan untuk mendeteksi infeksi yang disebabkan oleh infeksi yang sumbernya dari donor, organ visceral (infeksi intraabdomen pada transplantasi hati), luka pasca-operasi, aliran darah terkait penggunaan kateter, dan saluran napas bawah yang didapat di rumah sakit. ${ }^{1,2}$

Adanya infeksi ditandai dengan tanda dan gejala klinis berupa demam, sesak nafas, peradangan pada luka operasi. Pemeriksaan penunjang mencakup hematologi dasar, biakan darah dan urin, analisis urin, pemeriksaan apus tenggorok, luka, akses invasif (exit sites) dan marker infeksi seperti $C$-reactive protein (CRP), dan procalcitonin. Pada awal pascatransplantasi, pemeriksaan darah hematologi lengkap, kultur darah, urin dan sputum dilakukan setiap hari. Evaluasi dan tata laksana infeksi (empiris atau definitif) harus dilakukan setelah diskusi dalam tim transplan hati yang terdiri dari multidisiplin yang termasuk ahli gastrohepatologi, penyakit infeksi dan pediatri tropis, pulmonologi Anak, emergensi dan rawat inap intensif anak (ERIA), dan bedah anak. ${ }^{1,10}$

\section{b. Faktor risiko infeksi pasca-transplantasi}

Beberapa faktor risiko terjadinya infeksi pascatransplantasi, idealnya, telah diidentifikasi sebelumnya dan menjadi acuan untuk kriteria pemantauan terjadinya infeksi pasca-transplantasi. Faktor risiko tersebut di antaranya berupa faktor pasien, faktor donor, faktor operasi dan faktor pasca transplantasi. ${ }^{1}$ Faktor pasien meliputi, usia, skor the Pediatric End-Stage Liver Disease (PELD) $>15$, malnutrisi, perawatan rumah sakit dan penggunaan kateter yang lama sebelum transplantasi, gagal hati akut, riwayat infeksi sebelumnya (spontaneous bacterial peritonitis, sepsis,

Tabel 2. Ringkasan rekomendasi kebijakan kontrol infekesi MRSA dan VRE pada pasien dengan SOT ${ }^{1}$

\begin{tabular}{lcclc}
\hline $\begin{array}{l}\text { Pencegahan kontak } \\
\text { (contact precautions) }\end{array}$ & Ruangan isolasi & Kultur uji tapis & Dekolonisasi & $\begin{array}{c}\text { Pembersihan } \\
\text { lingkungan } \\
\text { (environment } \\
\text { cleaning) }\end{array}$ \\
\hline $\begin{array}{l}\text { MRSA } \\
\text { direkomendasikan }\end{array}$ & Direkomendasikan & $\begin{array}{l}\text { Direkomendasikan } \\
\text { sebelum transplantasi }\end{array}$ & $\begin{array}{l}\text { Pertimbangkan mandi } \\
\text { dengan clorhexidin pada area } \\
\text { dengan prevalensi tinggi } \\
\text { selama perawatan di ICU } \\
\text { Pertimbangkan mupyrocin } \\
\text { nasal untuk pasien di } \\
\text { bangsal konvensional }\end{array}$ & Direkomendasikan \\
& $\begin{array}{l}\text { Direkomendasikan } \\
\text { hanya selama area } \\
\text { dengan wabah } \\
\text { tinggi }\end{array}$ & $\begin{array}{l}\text { Direkomendasikan } \\
\text { atau pada prevalensi }\end{array}$ & Tidak direkomendasikan & Direkomendasikan \\
direkomendasikan & & & \\
\hline
\end{tabular}


pneumonia, CMV, dan infeksi saluran kemih), riwayat tuberkulosis, dan perawatan di ICU lebih dari 48 jam. Skor PELD merupakan skoring yang digunakan untuk menentukan keparahan penyakit hati kronis yang dapat memprediksi kematian pada anak yang menunggu transplantasi hati dengan rumus sebagai berikut: ${ }^{11}$

Rumus PELD=0,436 (usia ( $<1$ tahun)) $0,687 \times \log _{\mathrm{e}}$ (albumin g/dL) $+0,480 \times \log _{\mathrm{e}}$ (total bilirubin $\mathrm{mg} / \mathrm{dL})+1,87 \times \log _{\mathrm{e}}(\mathrm{INR})+0,667$ (growth failure (<-2 standar deviasi)

Skor PELD berkisar dari 6 (derajat penyakit ringan) hingga 40 (derajat penyakit berat). Resipien transplantasi hati dengan skor PELD yang lebih tinggi lebih diutamakan menerima transplantasi hati terlebih dahulu dibandingkan dengan skor yang lebih rendah. Semakin tinggi skor PELD maka semakin tinggi risiko kematian tanpa menerima transplantasi hati. ${ }^{12}$

Faktor donor ialah perawatan donor di ICU yang lama, infeksi donor, dan marginal graft. Faktor operasi ialah koledokojejunostomi, operasi lebih dari 12 jam, re-operasi dan re-transplantasi, serta transfusi masif lebih dari 15 unit. Faktor pascatransplantasi meliputi penggunaan ventilator, tingkat dan jenis imunosupresan (keterlibatan antibodi monoklonal atau poliklonal), trombosis, arteri hepar, trombosis vena porta, kolangitis iskemik, striktur bilier, dan fistel bilier, dan kolangitis sklerotik pasca-tranplantasi hati. ${ }^{1,13}$

Infeksi bakteri banyak didapatkan dua bulan pertama pasca-transplantasi. Infeksi bakteri umumnya menyebabkan infeksi pada luka operasi, infeksi intraabdomen, bakteremia, pneumonia, infeksi terkait penggunaan kateter, dan infeksi saluran kemih. ${ }^{14}$ Infeksi luka operasi merupakan kejadian yang dipengaruhi faktor epidemiologi bakteri lokal, faktor risiko infeksi, dan profilaksis antimikroba yang mencakup kuman gram positif dari flora normal kulit. Pada resipien transplantasi hati, infeksi terkait operasi (infeksi luka operasi, peritonitis, abses abdomen, dan abses hepar) dapat menyebabkan infeksi intraabdomen. Evaluasi infeksi intraabdomen adalah dengan modalitas pencitraan (CT scan atau USG abdomen) dan bila terdapat asites diperiksa jumlah nilai neutrofil dan kultur cairan asites serta kultur darah. Etiologi yang paling sering ditemukan adalah basil gram negatif dan Enterococcus spp, sementara patogen MDR lebih banyak ditemukan pada abses. ${ }^{14}$

Procalcitonin merupakan penanda diagnostik yang sahih untuk evaluasi komplikasi dan sepsis infeksi bakteri pasca-transplantasi. Penanda infeksi bakteri yang bermakna digunakan adalah nilai procalcitonin setelah hari ke-3 operasi. Peningkatan procalcitonin pada waktu awal setelah tranplantasi, dalam tiga hari pertama setelah transplantasi, tidak memiliki nilai prediktif untuk menilai disfungsi hati pasca-transplantasi hati maupun luaran yang mematikan. Beberapa penelitian menunjukkan superioritas procalcitonin dibandingkan $C$-reactive protein sebagai penanda infeksi dan sepsis.

Tabel 3. Evaluasi infeksi pasca-transplantasi berdasarkan lokasi ${ }^{1}$

\begin{tabular}{|c|c|c|c|}
\hline Infeksi & Keterangan & Evaluasi tingkat I & Evaluasi tingkat II \\
\hline Abdomen & $\begin{array}{l}\text { Risiko: durasi operasi dan re- } \\
\text { transplantasi }\end{array}$ & $\begin{array}{l}\text { Pemeriksaan darah lengkap, } \\
\text { pemeriksaan biakan urin dan } \\
\text { darah }\end{array}$ & $\begin{array}{c}\text { CT scan atau USG } \\
\text { Endoscopic retrograde cholangio- } \\
\text { pancreatography } \\
\text { Biopsi hati }\end{array}$ \\
\hline Luka operasi & $\begin{array}{l}\text { S. aureus, streptococci, Gram negatif } \\
\text { anaerob, jamur }\end{array}$ & $\begin{array}{c}\text { Pewarnaan Gram dan pemeriksaan } \\
\text { biakan pus }\end{array}$ & USG atau $C T$ scan \\
\hline Terkait kateter & $\begin{array}{c}\text { S. aureus, Enterococci, Pseudomonas, } \\
\text { Candida spp }\end{array}$ & $\begin{array}{l}\text { Pemeriksaan biakan darah (central } \\
\text { venous catheter dan vena perifer) }\end{array}$ & Ekokardiografi \\
\hline Saluran kemih & Basil Gram negatif, Enterococci & $\begin{array}{c}\text { Pemeriksaan biakan darah dan } \\
\text { urin }\end{array}$ & Pencitraan ginjal \\
\hline $\begin{array}{l}\text { Saluran napas } \\
\text { bawah }\end{array}$ & Basil Gram negatif, S.aureus & $\begin{array}{l}\text { Pemeriksaan biakan sputum dan } \\
\text { Rontgen toraks }\end{array}$ & $\begin{array}{c}\text { CT scan } \\
\text { Bronchoalveolar lavage } \\
\text { Torasentesis }\end{array}$ \\
\hline
\end{tabular}


Suatu penelitian pada 65 pasien transplantasi hati anak tahun 2007-2011 di Jerman menunjukkan bahwa panduan marker procalcitonin (PCT) pasca- transplantasi hati pada anak memiliki nilai cut-off median procalcitonin dalam 24 jam pertama pasca-transplantasi sebesar $5,16 \mu \mathrm{g} / \mathrm{L}$ (95\% CI 2,18-21,13). Nilai cut-off procalcitonin pada hari ke-7 sampai 10 pasca-transplantasi, tanpa demam minimal 1 minggu pre- dan pascapengukuran biomarker PCT: 0,170 $\mu \mathrm{g} / \mathrm{L}(95 \%$ CI 0,15-0,36). Nilai cut-off procalcitonin pada onset terjadi demam pasca-tranplamtasi hati adalah $1,93 \mu \mathrm{g} / \mathrm{L}$ (95\% CI 1,36-2,66) untuk infeksi bakteri; 0,19 $\mu \mathrm{g} / \mathrm{L}(95 \%$ CI1,10-0,48) untuk terjadi rejeksi; dan $0,31 \mu \mathrm{g} / \mathrm{L}(95 \%$ CI 0,15-0,44) untuk infeksi virus. ${ }^{14}$

Panduan marker procalcitonin pada pasien transplantasi hati anak di atas memberikan area under the curve ROC (AUROC) untuk PCT adalah 1,0 ( $<<0,0001)$, sedangkan CRP 0,842 (95\% CI 0,686-0,998; $\mathrm{p}<0,0001)$. Maka PCT merupakan marker yang terbukti paling spesifik

Tabel 4. Manajemen bakteri $\mathrm{MDR}^{7}$

\begin{tabular}{lc}
\hline Jenis bakteri MDR & Pilihan antibiotik \\
\hline VRE & Linezolid, Tigecycline \\
MRSA & Vancomycin, Linezolid \\
MDR Gram (-) & Carbapenem (hanya untuk non-carbapenemase) \\
& Colistin/Polymixin \\
& Tygecycline \\
\hline
\end{tabular}

Tabel 5. Rekomendasi pengendalian infeksi bakteri MDR pada transplantasi hati ${ }^{7}$

\begin{tabular}{|c|c|c|c|c|}
\hline & Pencegahan kontak & Ruangan iolasi & Dekolonisasi & $\begin{array}{l}\text { Pembersihan } \\
\text { lingkungan }\end{array}$ \\
\hline MRSA & Direkomendasikan & Direkomendasikan & $\begin{array}{l}\text { Mandi dengan clorhexidin } \\
\text { pada area dengan } \\
\text { prevalensi tinggi selama } \\
\text { rawat inap di ICU } \\
\text { Pertimbangkan mupyrocin } \\
\text { nasal untuk pasien dengan } \\
\text { koloni } \\
\text { Konvensional }\end{array}$ & Direkomendasikan \\
\hline VRE & Direkomendasikan & Direkomendasikan & $\begin{array}{l}\text { Tidak } \\
\text { direkomendasikan }\end{array}$ & Direkomendasikan \\
\hline ESBL-memproduksi E. coli & Direkomendasikan & $\begin{array}{l}\text { Tidak } \\
\text { direkomendasikan }\end{array}$ & $\begin{array}{l}\text { Tidak } \\
\text { direkomendasikan }\end{array}$ & $\begin{array}{l}\text { Direkomendasikan } \\
\text { selama outbreak } \\
\text { dan pilihan ketika } \\
\text { terjadi infeksi } \\
\text { epidemik }\end{array}$ \\
\hline $\begin{array}{l}\text { ESBL atau ampC- } \\
\text { memproduksi } \\
\text { Enterobacteriaceae (berbeda } \\
\text { dengan ESBL-producing E. } \\
\text { coli) }\end{array}$ & Direkomendasikan & Direkomendasikan & $\begin{array}{l}\text { Tidak } \\
\text { direkomendasikan }\end{array}$ & Direkomendasikan \\
\hline $\begin{array}{l}\text { KPC-memproduksi K. } \\
\text { pneumoniae MDR/XDR } \\
\text { non-fermentasi }\end{array}$ & Direkomendasikan & Direkomendasikan & $\begin{array}{l}\text { Tidak } \\
\text { direkomendasikan }\end{array}$ & Direkomendasikan \\
\hline Gram-negatif bacilli & Direkomendasikan & Direkomendasikan & $\begin{array}{l}\text { Tidak } \\
\text { direkomendasikan }\end{array}$ & Direkomendasikan \\
\hline
\end{tabular}


untuk membedakan infeksi bakteri dari infeksi virus dan rejeksi. ${ }^{15}$

Pemantauan terhadap MRSA, VRE, ESBL, dan carbapenemase-producing Gram-negative bacteria (GNB) perlu dilakukan setelah transplantasi untuk tata laksana pemberian antibiotik yang adekuat. Evaluasi infeksi pasca-transplantasi hati berdasarkan lokasi tertera pada Tabel 3.

\section{c. Infeksi karena bakteri MDR}

Infeksi karena bakteri MDR meningkat di dunia dan juga di Indonesia. Hal ini juga menimbulkan masalah pada pasien transplantasi hati. ${ }^{7}$ Kasus MDR dikonsulkan ke tim program pengendalian resistensi antibiotik (PPRA), yaitu ahli infeksi dan penyakit tropis, farmakologi klinik, mikrobiologi klinik, pencegahan pengendalian infeksi rumah sakit (PPIRS), dan ahli terkait lainnya. Antibiotik untuk bakteri MDR disesuaikan berdasarkan hasil kultur. Manajemen dan rekomendasi pengendalian infeksi bakteri MDR tertera pada Tabel 4 dan 5.

\section{Kesimpulan}

Infeksi bakteri merupakan penyebab morbiditas dan mortalitas terbesar pada anak pasca-transplantasi hati. Risiko infeksi bakteri pasca-transplantasi dipengaruhi berbagai macam faktor termasuk di dalamnya pajanan lingkungan dan adanya prosedur invasif. Uji tapis infeksi bakteri sebelum transplantasi penting dilakukan. Profilaksis pre- dan pasca-transplantasi juga berperan penting dalam proses transplantasi hati. Diperlukan protokol pre- dan pasca-transplantasi yang sesuai untuk mencegah dan mengurangi terjadinya infeksi bakteri pada anak yang menjalani transplantasi hati, sehingga morbiditas dan mortalitas pascatransplantasi hati menurun.

\section{Daftar pustaka}

1. Fagiuoli S, Colli A, Bruno R, dkk. Management of infections pre- and post-liver transplantation: report of a AISF consensus conference. J Hepatol 2014;60:1075-89.
2. Green M, Michaels MG. Infections in pediatric solid organ transplant recipients. JPIDS 2012;2:144-51.

3. Kim JE, Oh SH, Kim KM, dkk. Infections after living donor liver transplantation in children. J Korean Med Sci 2010;25:527-31.

4. Kim YJ, Kim SI, Choi JY, Yoon SK, You YK, Kim DG. Clinical significance of surveillance culture in liver transplant recipients. Transplant Proc 2014;46:828-31.

5. Kim SI. Bacterial infection after liver transplantation. World J Gastroenterol 2014;20:6211-20.

6. Nebraska Medicine. Transplant antimicrobial surgical prophylaxis order form.Diakses 30 Juni 2017. Didapat dari: https://www.nebraskamed.com/sites/default/files/documents/forproviders/asp/solid-organ-transplant.pdf.

7. Cervera C, Van Delden C, Gavalda J, dkk. Multidrug-resistant bacteria in solid organ transplant recipients. Clin Microbiol Infect 2014;20:49-73.

8. Behairy BE, Konsowa HA, Zakaria HM, Abd-Elsalam $\mathrm{OH}$, Sira MM. Infection after pediatric living related liver transplantation: timing, types and risk Factors.Int J Transplant Res Med 2015;1:3.

9. Romero FA, Razonable RR. Infections in liver transplant recipients. World J Hepatol 2011;3:83-92.

10. Rigg K. Kidney transplant guidelines. NHS. Diakses 30 Juni 2017. Didapat dari: https://www.nuh.nhs.uk/handlers/ downloads.ashx?id=60932.

11. McDiarmid SV, Merion RM, Dyskstra DM, Harper AM. Use of a pediatric end-stage liver disease score for deceased donor allocation: the United States experience. Indian J Pediatrics 2007;74:388-90.

12. The United Network for Organ Sharing. Questions and answers for transplant candidates about MELD and PELD. Diakses 20 Oktober 2018. Didapat dari: https://www.unos.org/ wp-content/uploads/unos/MELD_PELD.pdf.

13. Ferrarese A, Zanetto A, Becchetti C, Sciarrone SS, Shalaby S, Germani G, Gambato M, dkk. Management of bacterial infection in the liver transplant candidate. World J Hepatol 2018;10:22230.

14. Perrakis A, Strikat F, Croner R, dkk. Prognostic and diagnostic balue of procalcitonin in the post-transplant setting after liver transplantation. Arch Med Sci 2016;12:372-9.

15. Grammatikopoulus T, Dhawan A, Bansai S, dkk. Baseline evaluation of serum markers of inflammation and their utility in clinical practice in pediatric liver transplant recipients. Clin Res Hepatol Gastroenterol 2012;36:365-70. 